\title{
An Incidental Finding of a Double-Lumen Trachea
}

\section{Um Achado Incidental de Uma Traqueia de Duplo-Lúmen}

\begin{abstract}
Krzysztof PIERSIALA ${ }^{1,3}$, Anna LOROCH ${ }^{1}$, Joanna JACKOWSKA $\rrbracket^{2}$, Malgorzata WIERZBICKA ${ }^{2,4}$
Acta Med Port 2021 Mar;34(3):229-231 • https://doi.org/10.20344/amp.12000

ABSTRACT

The aim of this case report is to present an incidental finding of a firm tracheal septum in a 61-year-old woman. The patient was admitted to the hospital with mild dyspnea and a preliminary diagnosis of a tracheal subglottic stenosis. During microlaryngoscopy, just below the subglottic stenosis, a firm, vertical symphysis (septum), forming a double-lumen trachea was found. There was no record of any previous difficulties with intubation. A computed tomography scan performed after the microlaryngoscopy revealed an airway branch arising from the trachea at the level of thyroid gland and joining its lumen below. The radiological and endoscopic findings in the presented case hardly resemble the conditions described in the literature, as the discovered septum does not have a pseudomembranous nature, nor does it form a tracheal bronchus. Therefore, the finding is thought to be an unusual complication of multiple intubations in the past. This is an extremely rare finding and it is important to share our experience in managing a patient with the aforementioned post-intubation complications.
\end{abstract}

Keywords: Laryngoscopy; Tracheal; Tracheal Stenosis

\section{RESUMO}

O objetivo deste relato de caso é apresentar um achado incidental de um septo traqueal numa mulher de 61 anos. A paciente foi internada no hospital com dispneia leve e diagnóstico preliminar de estenose subglótica traqueal. A microlaringoscopia realizada mostrou uma sínfise vertical firme (septo) logo abaixo da estenose subglótica, formando uma traqueia de duplo lúmen. Não houve registo de qualquer dificuldade prévia com a intubação. A tomografia computadorizada realizada após a microlaringoscopia revelou um ramo da via aérea originando-se a partir da traquéia ao nível da glândula tiróide e unindo-se ao seu lúmen em baixo. Os achados radiológicos e endoscópicos do caso apresentado dificilmente se assemelham aos descritos na literatura, pois o septo descoberto não é pseudomembranoso, nem forma um brônquio traqueal. Assim, julga-se que o achado seja uma complicação pouco comum no contexto de múltiplas intubações no passado. Este é um achado extremamente raro pelo que é importante partilhar a nossa experiência no tratamento de um doente com as complicações pós-intubação supra-citadas.

Palavras-chave: Estenose da Traqueia; Laringoscopia; Traqueia

\section{INTRODUCTION}

The review of literature describing anomalies of tracheobronchial anatomy estimates the prevalence of congenital malformations to be $1 \%-12 \%$ among the population of patients undergoing diagnostic endoscopic procedures in intrathoracic airways. ${ }^{1}$ However, the majority of anomalies of tracheobronchial anatomy are caused by previous intubation. ${ }^{2}$ In this article, we present a case of a double-lumen trachea. This is an extremely rare complication of intubation and it is crucial to share our experience in management of patient with aforementioned tracheal malformation, especially due to the fact that radiologic and endoscopic findings in this case are unusual for acquired, post-intubation complication.

\section{CASE REPORT}

We present the case of a 61-year-old female with an incidentally found double-lumen trachea. Microolaryngoscopy was performed because of the patient's subglottic stenosis and it showed a firm vertical tracheal septum forming a double-lumen trachea. The patient was admitted to the hospital with mild dyspnea associated with an upper res- piratory tract infection (URTI) and preliminary diagnosis of a tracheal subglottic stenosis visualized in laryngoscopy (the narrowest part measuring $7.5 \mathrm{~mm}$ ). During surgery, just under the subglottic stenosis, a firm, vertical symphysis (septum), forming a double-lumen trachea was found in microlaryngoscopy (Fig. 1). The stiffness of the septum prevented the tracheoscope from passing through. The patient's history, however, did not include previous difficulties with intubation (during nephrectomy, laparoscopy, or hysteroscopy). The patient suffered also from an episode of tracheitis and pneumonia earlier that year. A computed tomography scan performed after the endoscopic examination revealed an airway branch with a $7 \mathrm{~mm}$ diameter arising from the trachea at the level of the thyroid gland and joining its lumen $20 \mathrm{~mm}$ below (Fig. 2).

The mechanical balloon dilatation of the tracheal stenosis located above the septum was performed leaving the tracheal septum intact. As the patient's general condition after the procedure was stable and she did not experience difficulties in breathing, the patient was discharged home and instructed to return for follow-up in the outpatient

\footnotetext{
1. Student Research Group. Department of Otolaryngology, Head and Neck Surgery. University of Medical Sciences. Poznań. Poland.

2. Department of Otolaryngology, Head and Neck Surgery. University of Medical Sciences. Poznań. Poland.

3. Division of Ear, Nose and Throat Diseases. Department of Clinical Sciences. Intervention and Technology. Karolinska Institutet. Stockholm. Sweden.

4. Institute of Human Genetics. Polish Academy of Sciences. Poznań. Poland.

$\triangle$ Autor correspondente: Joanna Jackowska. driackowska@gmail.com

Recebido: 01 de março de 2019 - Aceite: 23 de setembro de 2019 - Online issue published: 01 de março de 2021

Copyright @ Ordem dos Médicos 2021
} 


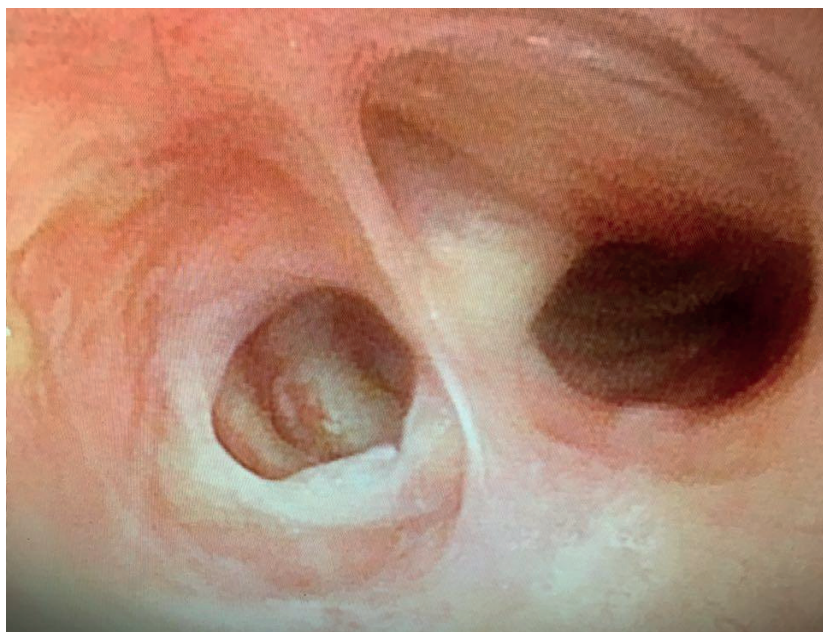

Figure 1 - Double-lumen trachea visualized during laryngoscopy

setting. After six months, a bronchofiberoscopy was performed showing good result of previous tracheal stenosis dilatation. The tracheal anomaly was still present and unchanged compared to the previous examination.

\section{DISCUSSION}

A review of the literature on such anomalies suggests 1) tracheal bronchus, 2) obstructive pseudomembranes (as a complication of endotracheal intubation or infections), 3) pleural junctional line that could give a false impression of a septum in diagnostic imaging or 4) tracheal secretions.

Congenital defects of the lower airways are mostly clinically relevant, in which case they are usually diagnosed and managed early in life, However, they may also not manifest clinically and therefore become fortuitous findings. ${ }^{3-5}$ They can also be associated with other syndromes. Tracheal bronchus represents one of the congenital anomalies that rarely bears any clinical relevance ${ }^{6}$ but is not an uncommon finding, with $0.1 \%$ - $5 \%$ incidence during bronchoscopy. ${ }^{7}$ Tracheal bronchi form as a result of abnormal evolution of the lung buds in the gestational period, arise mostly from the middle or lower parts of the trachea ${ }^{6}$ and are directed towards the upper lobes. ${ }^{8}$ As it can also be associated with tracheal stenosis, a tracheal bronchus could seem like a plausible differential diagnosis for our patient's malformation. In this case, however, the airway branch leaves the trachea only to join its lumen $2 \mathrm{~cm}$ below.

Preoperatively, one of the most probable causes of tracheal stenosis was presumably a stenosis secondary to endotracheal intubation. The patient underwent three independent surgeries (nephrectomy, laparoscopy, hysteroscopy) in the past, under general anesthesia with the use of endotracheal tubes. Despite the increasing awareness of the possible complications of incorrect or prolonged intubation among intensive care teams, the incidence of tracheal stenosis with this etiology remains high. ${ }^{9} \mathrm{~A}$ cuff pressure over $30 \mathrm{mmHg}$ can lead to mucosal ischemia and consequently damage in the cartilage structure. If present, it may eventually cause fibrosis and circumferential stenosis of the trachea. ${ }^{10}$ The most commonly observed sign of this finding is dyspnea, the severity of which depends on the degree of stenosis. Mild cases of subglottic stenosis may not require surgical treatment. In severe cases, surgical treatment is needed, and surgical procedures might be categorized into open or endoscopic neck surgery with resection of stenotic
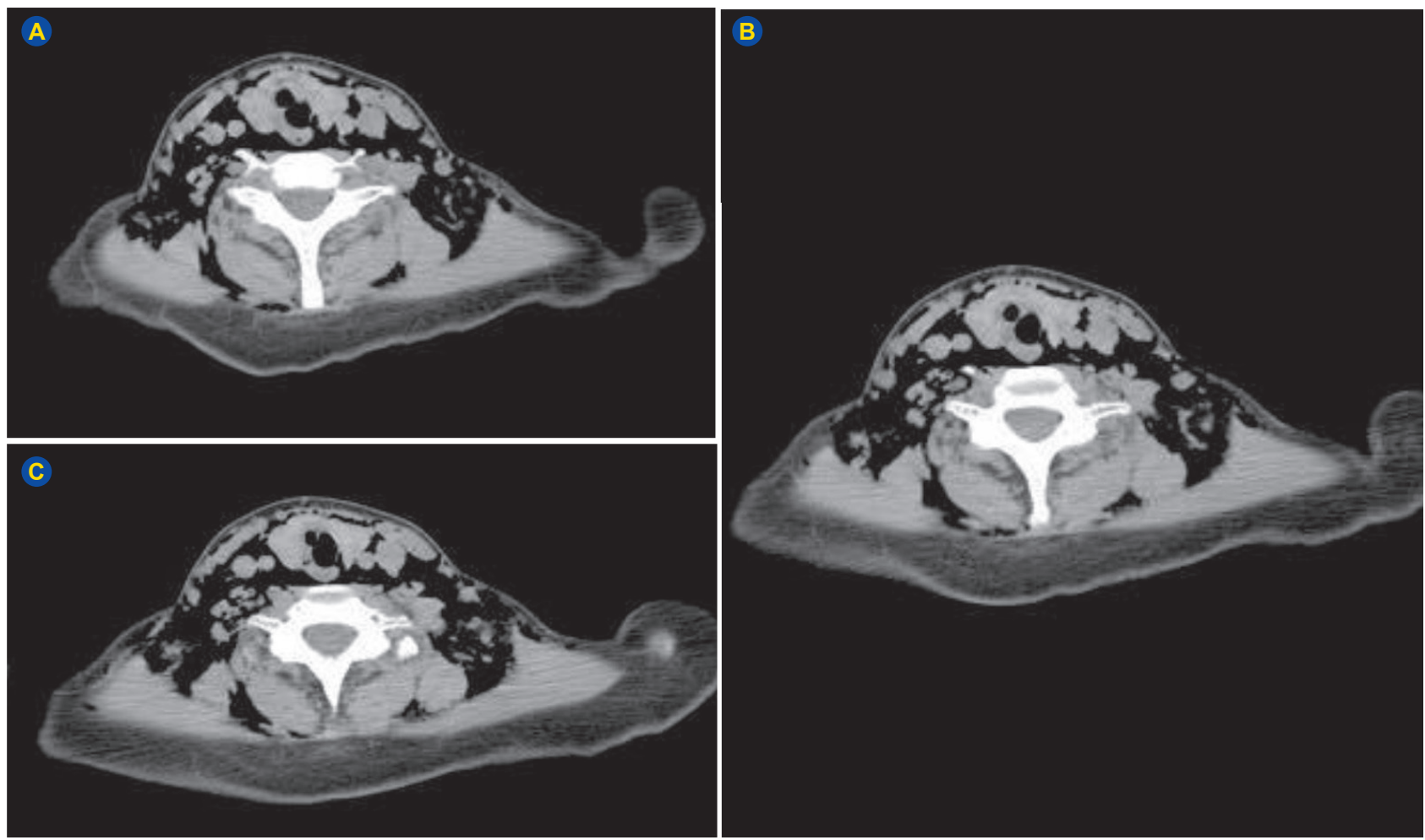

Figure 2 - CT scan showing an airway branch with a $7 \mathrm{~mm}$ diameter arising from the trachea at the level of thyroid gland (A) and joining its lumen $20 \mathrm{~mm}$ below (C) 
fragment or endoscopic mechanical dilatation by balloons or rigid instruments.

The other common causes of tracheal stenosis in adults are infectious or inflammatory diseases. ${ }^{11}$ This could be considered in this case as the patient was treated for tracheitis in the past. However, both causes were excluded intraoperatively, as the observed picture of a firm septum dividing the lumen of the trachea did not morphologically resemble these suspected entities.

Pseudomembrane is also a likely explanation for a septum formed in the trachea. It could either have an idiopathic or post-infectious etiology. As a complication of endotracheal intubation, it is rare and could be severe - it may induce a life-threatening obstruction of the airways ${ }^{12}$ and may present itself as atelectasis, respiratory infection ${ }^{13,14}$ or post-extubation stridor. ${ }^{15}$ Its appearance is explained by the mucosal ischemia caused by the intubation tube, resulting in overproduction of growth factors ${ }^{16}$ or secretions. ${ }^{13}$ Most of them, however, overlie the tracheal mucous membrane, slowly causing obstruction, instead of presenting as a vertical septum in the trachea.

The radiological and endoscopic findings in the presented case do not resemble any condition described in the literature. Therefore, the theory about a congenital defect with minor influence on the patient's clinical condition cannot be rejected. However, the patient's history of uncomplicated previous intubations and recent tracheitis strongly refute this thesis. Thus, we hypothesized that in this case the most probable explanation for the cause of this lesionis an uncommon presentation of complications resulting from endotracheal intubation. It is essential to perform a bron- chofiberoscopy regularly as well as a thorough observation of the patient. So far, we assume that the tracheal septum is clinically irrelevant, even though it may predispose to dyspnea or inflammation. Although this anomaly is a rare finding in humans, it is important for clinicians to be aware of its presence. This case report suggests that a double-lumen trachea is not a life-threatening condition and it can be managed with a 'watch and wait' approach.

\section{PROTECTION OF HUMANS AND ANIMALS}

The authors declare that the procedures were followed according to the regulations established by the Clinical Research and Ethics Committee and to the Helsinki Declaration of the World Medical Association updated in 2013.

\section{DATA CONFIDENTIALITY}

The authors declare having followed the protocols in use at their working center regarding patients' data publication.

\section{INFORMED CONSENT}

Obtained.

\section{CONFLICTS OF INTEREST}

The authors declare that there is no conflict of interest No funding was received for this project.

\section{FUNDING SOURCES}

The authors declare that there were no external sources of study for the performance of this article.

\section{REFERENCES}

1. McDonough RJ, Niven AS, Havenstrite KA. Congenital pulmonary airway malformation: a case report and review of the literature. Respirat Care. 2012;57:302-6.

2. Wain JC. Postintubation tracheal stenosis. Semin Thorac Cardiovasc Surg. 2009;21:284-9.

3. Graça A, Lucas M, Pereira L, Barreto C, Lobo L, Gonçalves M, et al. Sliding tracheoplasty: a good choice for the treatment of congenital tracheal stenosis. Acta Med Port. 2004;17:247-52.

4. Oliveira-Santos JA, Pereira-da-Silva L, Clington A, Serelha M. Neonatal bronchoscopy: a retrospective analysis of 67 cases and a review of their indications. Acta Med Port. 2004;17:341-8.

5. Gonlugur U, Efeoglu T, Kaptanoglu M, Akkurt I. Major anatomical variations of the tracheobronchial tree: bronchoscopic observation. Anat Sci Int. 2005;80;111-5.

6. Zach MS, Eber E. Adult outcome of congenital lower respiratory tract malformations. Thorax. 2001;56:65-72.

7. Ruchonnet-Metrailler I, Abou Taam R, de Blic J. Presence of tracheal bronchus in children undergoing flexible bronchoscopy. Respirat Med. 2015;109:846-50.

8. Setty SP, Michaels AJ. Tracheal bronchus: case presentation, literature review, and discussion. J Trauma. 2000;49:943-5.

9. Donatelli J, Gupta A, Santhosh R, Hazelton TR, Nallamshetty L, Macias A, et al. To breathe or not to breathe: a review of artificial airway placement and related complications. Emerg Radiol. 2014;22:171-9.

10. De S, De S. Post intubation tracheal stenosis. Indian J Crit Care Med. 2008;12:194-7

11. Abdala FA. Benign tracheal stenosis. Chest Surgery. Berlin Heidelberg: Springer; 2015;31-40.

12. Desir A, Ghaye B. Congenital abnormalities of intrathoracic airways Radiol Clin North Am. 2009;47:203-25.

13. Sehgal IS, Dhooria S, Bal A, Aggarwal AN, Behera D, Agarwal R. Obstructive fibrinous tracheal pseudomembrane after endotracheal intubation. Respir Care. 2016;61:1260-6.

14. Arenas-de Larriva M del S, Cosano-Povedano J, Cosano-Povedano A. Inflammatory tracheal pseudomembrane. Arch Bronconeumol. 2014;50:307-8.

15. Crespo-Lessmann A, Torrego-Fernández A. Obstructive inflammatory tracheal pseudomembrane. Arch Bronconeumol. 2013;49:402-4.

16. Fiorelli A, Vicidomini G, Messina G, Santini M. Spontaneous expectoration of an obstructive fibrinous tracheal pseudomembrane after tracheal intubation. Eur J Cardiothorac Surg. 2011;40:261-3. 